\title{
\#USGS

Major-Element, Sulfur, and Chlorine

Compositions of Glasses from the Submarine Flank of Kilauea Volcano, Hawaii, Collected During 1998-2002 Japan Marine Science and Technology Center (JAMSTEC) Cruises

By Michelle L. Coombs ${ }^{1}$, Thomas W. Sisson ${ }^{2}$, and Peter W. Lipman ${ }^{2}$

Open-File Report 2004-1378

2004

Any use of trade, firm, or product names is for descriptive purposes only and does not imply endorsement by the U.S. Government.

U.S. DEPARTMENT OF THE INTERIOR

U.S. GEOLOGICAL SURVEY

${ }^{1}$ Alaska Volcano Observatory, Anchorage, Alaska

${ }^{2}$ Menlo Park, California 


\section{Introduction}

From 1998 to 2002, four cruises by Japan Marine Science and Technology Center (JAMSTEC) research vessels explored the submarine flanks of the Hawaiian Islands (Naka and others, 2002; Takahashi and others, 2002). This collaborative Japan-USA research program resulted in new multibeam mapping of the seafloor around Hawai ' $i$ (Eakins and others, 2003), and seafloor observation and sample collection during 53 manned submersible and 25 remotely-operated vehicle (ROV) dives. In this report, we present major element, $\mathrm{S}$, and $\mathrm{Cl}$ compositions of volcanic glasses collected from the submarine flanks of Killauea Volcano during the JAMSTEC research program. The compositions were determined by electron probe microanalysis (EPMA) at the USGS in Menlo Park, California.

The submarine portion of Killauea, Hawai 'i's most active volcano, was a main target during the JAMSTEC program (Figure 1), with 15 manned submersible dives and seven ROV dives. Dive observations revealed that much of the volcano's south flank, manifested as the midslope bench, consists of volcaniclastic debris, shed from the volcano as turbidites and debris flows (Lipman and others, 2002). Debris exposed in the outer scarp of the midslope bench spans a large compositional range and records the pre-shield, alkalic phase for this volcano (Lipman and others, 2002; Sisson and others, 2002). Coarser debris (breccia clasts) is almost certainly from Kìlauea, as are most alkalic sands. For low-S, tholeiitic sand grains, the source volcanoes are probably Mauna Loa and perhaps Mauna Kea (Lipman and others, 2002; Sisson and others, 2002).

Dives on the upper slope of Killauea's south flank and along Puna Ridge, the submarine extension of the volcano's east rift zone, encountered in-place tholeiitic, transitional, and mildly alkalic pillow lavas of the primary volcanic edifice (Johnson and others, 2002; Lipman and others, 2002; Sisson and others, 2002). All sampled pillow lavas are unequivocally from Kìlauea.

In addition to the outer scarp of the midslope bench and the primary volcanic edifice, JAMSTEC dives sampled several other surrounding features (Figure 1). Punalu'u slump clasts are likely derived from Mauna Loa Volcano (Lipman and others, 2002). A ridge southeast of Lo'ihi Seamount probably contains material from Lo'ihi and other sources. Breccia clast rinds from Papa'u Seamount are likely derived from Mauna Loa 
Volcano (Kimura and others, 2002). Supra-bench breccias contain material from Kìlauea, Mauna Loa and maybe Mauna Kea (Coombs and others, 2004).

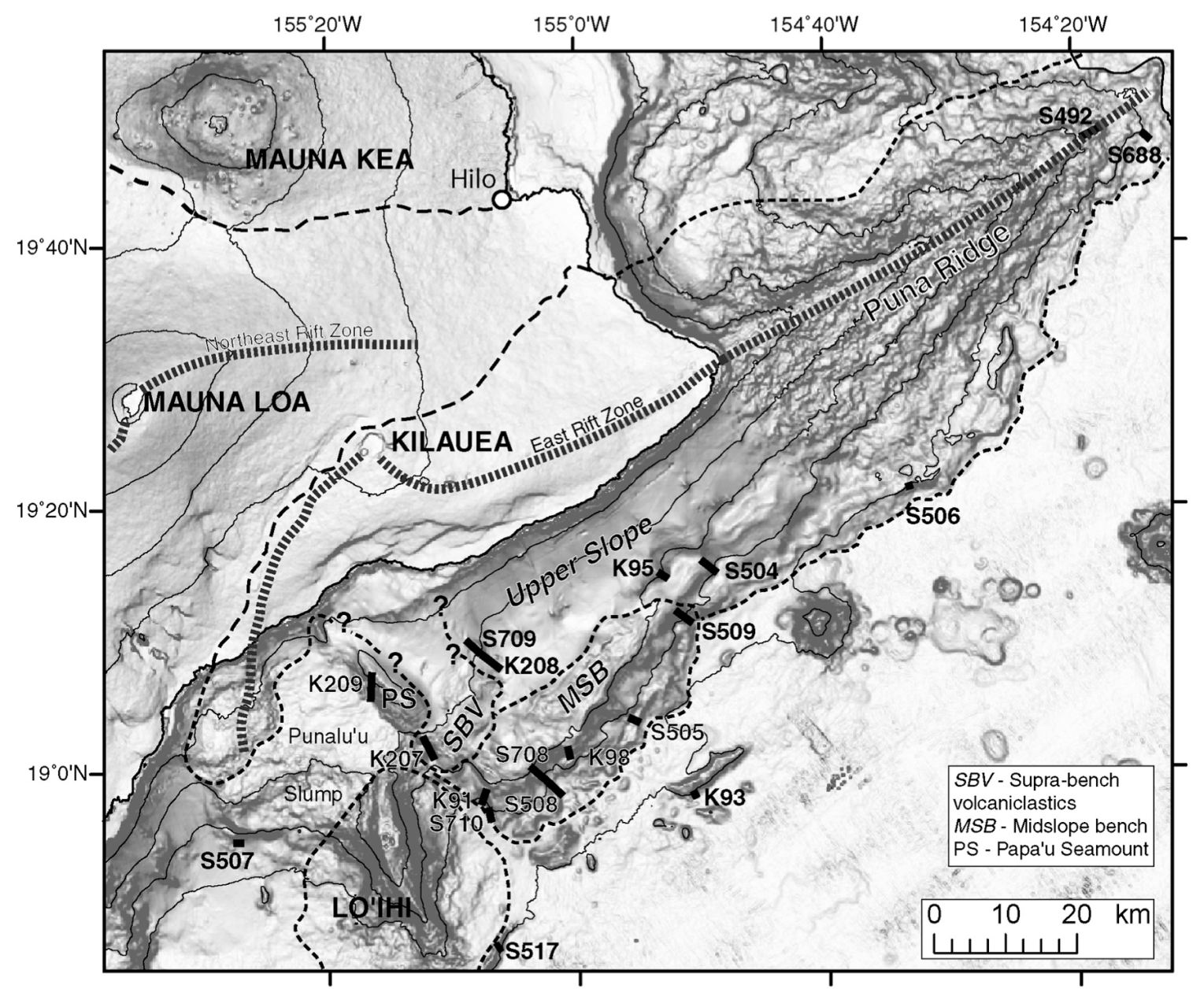

Figure 1. Shaded slope map of southern Hawai'i Island and surrounding sea floor. Shoreline, solid bold black line; $1000 \mathrm{~m}$ contours, thin black lines. Subaerial volcano boundaries and rift zones adapted from Wolfe and Morris (1996). Dive sites, thick black lines: Shinkai 6500 (S-prefix), Kaiko (K-prefix). South flank domains include the upper slope, midslope bench, and supra-bench volcaniclastics.

Dives were conducted by two JAMSTEC vehicles: the ROV Kaiko in 1998 and 2001, and the manned submersible Shinkai 6500 in 1999 and 2002. The vehicles are operated from the R/Vs Kairei and Yokosuka, respectively. Both vehicles have depth limits well beyond the depths encountered around Hawaii and thus provided the first access to the deepest portions of Kìlauea and other areas. Regardless of the vehicle, efforts were made to sample rocks directly from outcrop when possible, although some talus was collected where outcrops were not available. Kîlauea-area dive details, including exact location, 
depth, and outcrop descriptions for 1998 and 1999 dives are presented in Lipman and others (2002).

\section{Acknowledgements}

This work would not have been possible without the skilled crew of the JAMSTEC research vessels Kairei and Yokosuka, and the operational teams for the ROV Kaiko and the manned submersible Shinkai 6500. We thank the chief scientists of the JAMSTEC Hawai 'i cruises for their guidance and support: T. Kanamatsu, J. Naka, and E. Takahashi. We also appreciate the efforts of the shipboard scientific teams, especially those members who acted as dive observers during Killauea dives. R. Oscarson maintains the electron probe laboratory in Menlo Park and helped with sample preparation. Reviews by C. Thornber and K. Wallace helped to clarify our presentation of the data.

\section{Analytical Techniques}

The glass data in this report include four main sample types: glassy rinds of in-place pillow lavas, glass rinds on clasts from debris-flow breccias, glass sand grains adhered to breccia clasts, and glass grains from lithified volcaniclastic sandstones (hyaloclastite). Reported glass compositions are the averages of 10-15 spot analyses for pillow and breccia clast rinds, and three spot analyses for sand grains; background intensities were determined 1-3 times for each grain.

Analyses were conducted using wavelength dispersive techniques with a 5spectrometer JEOL 8900R electron microprobe at the USGS in Menlo Park, California. All analyses used a $20 \mu \mathrm{m}$ diameter beam with $25 \mathrm{nA}$ current and $15 \mathrm{kV}$ accelerating potential. Count times were 15-20 seconds for $\mathrm{Na}$, which was analyzed first to reduce Na-loss, 40 seconds for most elements, and 40-80 seconds for $\mathrm{S}$ and $\mathrm{Cl}$. Concentrations were determined with the CIT-ZAF reduction scheme (Armstrong, 1995). During analysis, sets of 5-10 replicate analyses of USNM glass standards VG2 and A99 (Jarosewich and others, 1979) were performed to monitor instrument drift.

Natural glass and mineral standards were used for calibration: glass A99 for $\mathrm{Si}$; glass VG2 for $\mathrm{Na}, \mathrm{Mg}, \mathrm{Fe}, \mathrm{Al}$, and $\mathrm{Ca} ; \mathrm{Mn}_{2} \mathrm{O}_{3}$ for $\mathrm{Mn}$; $\mathrm{TiO}_{2}$ for Ti; glass $\mathrm{GSC}$ for $\mathrm{K}$; Sodalite for $\mathrm{Cl}$; Wilberforce apatite for $\mathrm{P}$; and Barite for $\mathrm{S}$. These are the same standards used for several studies of Hawaiian basaltic glasses (for example, Clague and others, 1995; Thornber and others, 2002), with the exception of Si, for which VG2 has typically been used. During the course of this study, however, we recognized that using VG2 
produces $\mathrm{SiO}_{2}$ values for other glass working standards (A99, JB-2) that are generally high by several tenths of a weight percent. This prompted us to retroactively adjust our older glass analyses to correct for this deficiency. This was done by multiplying original $\mathrm{SiO}_{2}$ values for unknowns by 0.991 (average analyzed $\mathrm{A} 99 \mathrm{SiO}_{2}$ value divided by accepted $\mathrm{A} 99$ $\mathrm{SiO}_{2}$ value). Relative precision, as estimated from averages and standard deviations of repeated analyses of A- 99 and VG-2, is $\sim 0.5 \%$ for $\mathrm{SiO}_{2},<2 \%$ for $\mathrm{Al}_{2} \mathrm{O}_{3}, \mathrm{FeO}, \mathrm{MgO}$, and $\mathrm{CaO},<5 \%$ for $\mathrm{TiO}_{2}, \mathrm{Na}_{2} \mathrm{O}$, and $\mathrm{K}_{2} \mathrm{O}$, and $<10 \%$ for $\mathrm{MnO}$ and $\mathrm{P}_{2} \mathrm{O}_{5}$. Relative precision for $\mathrm{S}$ is $<10 \%$ for higher abundances (as represented by VG2; $1200 \mathrm{ppm}$ ), but $\sim 30 \%$ for lower S concentrations (A99, $100 \mathrm{ppm} \mathrm{S}$ ). Relative precision for $\mathrm{Cl}$ is less than $\sim 20 \%$ for measured standards. We have reported values of $<100 \mathrm{ppm}$ for both elements, but the detection limit for both may be around this value (Thornber et al., 2002). Published values for these standards are generally within one standard deviation of our analyzed values (except $\mathrm{SiO}_{2}$ for A99, as discussed above). Standard deviations of averages of multiple spot analyses for single unknown samples are generally within those listed above for working standards.

Some of the data presented here were previously published (Coombs and others, 2004; Sisson, 2003; Sisson and others, 2002). For sample compositions presented in Sisson et al. (2002), we have adjusted the $\mathrm{SiO}_{2}$ values to be consistent with the new A99 standardization; this results in slight differences in $\mathrm{SiO}_{2}$ values and totals for the two datasets.

\section{Explanation of the Data File}

The data are presented in an Excel workbook format. The first worksheet contains average standard compositions, as analyzed during the course of this study (1998-2003). Following is a series of eight worksheets that contain the glass data. These are organized geographically, generally from the southwest to the northeast. Each glass data worksheet is organized in the same fashion. The sample number prefix (for example, "S506-") indicates the dive during which each sample was collected. Prefixes beginning with an $\mathrm{S}$ indicate Shinkai dives, prefixes beginning with a $\mathrm{K}$ indicate Kaiko dives. The number immediately following the $\mathrm{S}$ or $\mathrm{K}$ shows the dive number. The prefix is followed by the sample number. For rock samples that contain many glass grains (such as the indurated sandstones), the sample number is then followed by a number (usually 1-25 for each sandstone sample; 50 grains were analyzed for particularly diverse sandstones) indicating the individual glass 
grains analyzed within each sandstone. Oxides are presented in weight percent, and $\mathrm{Cl}$ and $\mathrm{S}$ are presented in parts per million (ppm).

The last worksheet, "sample locations," lists the dives in chronological order, and gives latitude and longitude (in decimal degrees) and collection depth (in meters below sea level) for each sample location. Also shown for each sample are rock type, location description, and the best estimate for whether a sample was collected from outcrop or talus.

\section{References cited}

Armstrong, J.T., 1995, CITZAF: a package of correction programs for the quantitative electron microbeam X-ray analysis of thick polished materials, thin films, and particles: Microbeam Analysis, v. 4, p. 177-200.

Clague, D.A., Moore, J.G., Dixon, J.E., and Friesen, W.B., 1995, Petrology of submarine lavas from Kilauea's Puna Ridge, Hawaii: Journal of Petrology, v. 36, no. 2, p. 299-349.

Coombs, M.L., Sisson, T.W., and Kimura, J., 2004, Ultra-high chlorine in submarine Kilauea glasses: Evidence for direct assimilation of brine by magma: Earth and Planetary Science Letters, v. 217, p. 297-313.

Eakins, B.W., Robinson, J.E., Kanamatsu, T., Naka, J., Smith, D.K., Takahashi, E., and Clague, D.A., 2003, Hawaii volcanoes revealed: U.S. Geological Survey Geological Map Investigation Series, v. I-2809.

Jarosewich, E., Nelen, J.A., and Nordberg, J.A., 1979, Electron microprobe reference samples for standard analysis: Smithsonian Contributions to the Earth Sciences, v. 22, p. 68-72.

Johnson, K.T.M., Reynolds, J.R., Vonderhaar, D., Smith, D.K., and Kong, L.S.L., 2002, Petrological systematics of submarine basalt glasses from the Puna Ridge, Hawai' $\mathrm{i}$ : Implications for rift zone plumbing and magmatic processes, in Takahashi, E., Lipman, P., Garcia, M., Naka, J., and Aramaki, S., eds., Hawaiian Volcanoes: Deep Underwater Perspectives: Washington, D.C, American Geophysical Union, p. 143-159.

Kimura, J., Sisson, T., Coombs, M., and Lipman, P., 2002, In-place alkalic lavas recovered from Hilina bench, offshore Kilauea, Hawaii: Significance in reconstructing ancient Kilauea history: Transactions, American Geophysical Union, v. 83, no. 47, p. F1433.

Lipman, P., Sisson, T., Ui, T., Naka, J., and Smith, J., 2002, Ancestral submarine growth of Kilauea volcano and instability of its south flank, in Takahashi, E., Lipman, P., Garcia, M., Naka, J., and Aramaki, S., eds., Hawaiian Volcanoes: Deep Underwater Perspectives: Washington, D.C, American Geophysical Union, p. 161191.

Naka, J., Kanamatsu, T., Lipman, P.W., Sisson, T.W., Tsuboyama, N., Morgan, J.K., Smith, J.R., and Ui, T., 2002, Deep-sea volcaniclastic sedimentation around the southern flank of Hawaii, in Takahashi, E., Lipman, P., Garcia, M., Naka, J., and Aramaki, S., eds., Hawaiian Volcanoes: Deep Underwater Perspectives: Geophysical Monograph: Washington, D.C., American Geophysical Union, p. 2950.

Sisson, T., 2003, Native gold in a Hawaiian alkalic magma: Economic Geology, v. 98, p. 643-648. 
Sisson, T., Lipman, P., and Naka, J., 2002, Submarine alkalic through tholeiitic shieldstage development of Kilauea volcano, Hawaii, in Takahashi, E., Lipman, P., Garcia, M., Naka, J., and Aramaki, S., eds., Hawaiian Volcanoes: Deep

Underwater Perspectives: Washington, D.C, American Geophysical Union, p. 193219.

Takahashi, E., Lipman, P.W., Garcia, M.O., Naka, J., and Aramaki, S., eds., 2002, Hawaiian volcanoes: Deep underwater perspectives: Geophysical Monograph: Washington, DC, American Geophysical Union, v. 128, 418 p.

Thornber, C.R., Sherrod, D.R., Siems, D.F., Heliker, C.C., Meeker, G.P., Oscarson, R.L., and Kauahikaua, J.P., 2002, Whole-rock and glass major-element geochemistry of Kilauea Volcano, Hawaii, near-vent eruptive products; September 1994 through September 2001: U.S. Geological Survey, v. OF 02-0017. 